OPEN ACCESS

Vol. 6, No. 2, October, 2018

Page. 97 - 104
JOURNAL OF AUDITING, FINANCE, AND FORENSIC ACCOUNTING (JAFFA)

E-ISSN: 2461-0607 ISSN: 2339-2886

http://jaffa.trunojoyo.ac.id/jaffa

\title{
THE IMPACT OF ETHICAL JUDGMENT, LOCUS OF CONTROL, AND ORGANIZATIONAL COMMITMENTS TO WHISTLEBLOWING
}

\author{
Andreani Hanjani, Agus Purwanto, RR Karlina Aprilia Kusumadewi \\ Accounting Department, Faculty of Economics and Business, Diponegoro University
}

\section{Article Info:}

Received: 23 Februari 2018

in revised form: 19 June 2018

Accepted: 15 August 2018

Available Online: 5 October 2018

\section{Keywords:}

Ethical Judgment, Locus Of Control, Organizational Commitment, Intention Auditor, Whistleblowing.

\section{Corresponding Author:}

Email: ani.andreanjani@gmail.com; karlinaaprilia18@gmail.com;

agsp_sis@yahoo.com
Abstract; This research aims at examining the influence of ethical judgment, locus of control and organizational commitment of auditor intention to whistleblowing. The population of this research was all internal auditors in Central Java Inspectorate, Semarang Regency and Semarang City. Data used in this research were primary data, which were obtained with questionnaire survey method. Analysis method used was multiple regression. The result of this research showed that ethical judgement, locus of control and organizational commitments have positive and significant influence to auditor intention in doing whistleblowing. Meanwhile, gender has no significant influence to whistleblowing. Besides, the age has significant impact toward negative to whistleblowing intensity.

Abstrak; Tujuan penelitian ini untuk menguji pengaruh penilaian etis, locus of control, dan komitmen organisasi terhadap niat auditor untuk whistleblowing. Populasi penelitian adalah semua auditor internal di Inspektorat Jawa Tengah, Kabupaten Semarang dan Kota Semarang. Data yang digunakan dalam penelitian ini adalah data primer, yang dilakukan dengan menggunakan metode survei kuesioner. Metode pengolahan yang digunakan adalah analisis regresi berganda. Hasil penelitian menunjukkan bahwa penilaian etis, locus of control, dan komitmen organisasi berpengaruh positif dan signifikan terhadap niat auditor untuk melakukan whistleblowing. Sedangkan jenis kelamin tidak berpengaruh signifikan terhadap niat auditor untuk melakukan whistleblowing. Selain itu, usia berpengaruh signifikan terhadap intensitas whistleblowing arah negatif 


\section{INTRODUCTION}

Whistleblowing has been a public attention in the last few years. This is caused by many big companies doing fraud and finally detected. One of the accounting fraud cases ever happened was WorldCom. The price of WorldCom's stock fell down from \$150 billion in 2000 into $\$ 150$ million in 2002. This is caused by WorldCom financial report that claimed network load as the capital expenditure instead of load (Sulistomo, 2011).

In Indonesia, the revealing of the fraud cases also took place in government institution. It was like Susno Duadji revealing the tax evasion cases done by Gayus Tambunan as an employee at Tax General Directorate. Another business fraud that involved the role of whistleblower was case of bribe in Indonesian Bank (BI) done by Agus Condro.

The revealing of the cases cannot be separated from a person having bravery to expose a fraud in his company. The person having the bravery is called a whistleblower. One of famous whistleblowers is Cynthia Cooper, a Vice President of internal audit division in WorldCom company. She reported unethical practices in WorldCom when the company was failed to gain expected profit. The accounting fraud resulted in restatement for $\$ 9$ billion as the biggest amount as long as United State history (Duska, et al, 2011). Therefore, factors influencing whistleblowing intention is important matter to be studied in reaching the purposes of an organization.

Auditor is one of professions requiring professional ethics in carrying out his work. An external auditor has tasks to ensure that financial report resulted is appropriate with generally accepted accounting, meanwhile an internal auditor has task ascertain that audited organization is appropriate with the standard determined by directors board and also confirm the effectiveness and the efficiency of the organization or the company. In carrying out its duties, Government internal auditors have to obey with ethical code of APIP regulated on Minister of State Apparatus Empowerment No.PER/05/M.PAN/03/2008 dated 2008, 31 st March. On the other hand, government internal auditors should know and obey the ethical code of Indonesian accountants and audit standard ruled in Public Accountants Profession Standard assigned by IAI.

Prosocial behavior becomes supporting theory of whistleblowing. Brief and Motowidlo (1986) stated that whistleblowing is one of 13 forms of prosocial organizational behaviour. One of the behaviours is objection of_organizational members to the directions, procedures or policies which is probably considered unethical, illegal or bringing to a disaster of organization in long term, but they cannot show or change directly. He probably can do whistleblowing and report it to the individual or agency having tasks to correct it.

Another factor influencing the intention to do whistleblowing is locus of control. A person having internal locus of control tends to determine or rely on himself about right or wrong and is more responsible of his behavior. Whistleblowing is considered as an ethical action, so it is expected that the candidate of whistleblower tends to have internal locus of control characters.

Another variable explaining the possibility of individual whistleblowing behaviour is organizational commitment. Employees who have commitment to the organization will show positive behaviour and attitude, have spirit to protect their institution, attempt to increase achievements, and have a belief to implement organizational goals (Kuryanto, 2011).

The effort to realize good and clean governance, the government of Central Java Province has slogan "Mboten Korupsi Mboten Ngapusi" (no corruption, no lying) for better Central Java. This program emphasizes the importance of inspectorate tasks when they are in field without influencing of gratification or other grantings as ruled with Governor Rule of Central Java, Number 59, year 2014 on Guidance of Gratification Control in Central Java Province. Inspectorates in Central Java must be a whistleblower to reveal corruption in Central Java without accepting gratification that previously makes the inspectorate always closes corruption found after accepting gratification.

Committee of Investigation and Eradication for Corruption, Collusion and Nepotism in Central Java recorded the increasing 100\% of corruption cases in 2012 compared with 102 cases revealed in 2011. In 2013, corruption increased into seven cases compared with 2012. Moreover, there were 222 corruption cases in 2013. 
Semarang city was at the top rank as the most corruptive city/regency in 2013. In addition, 16 corruption cases occurred in the capital of Central Java. Those cases have resulted in loss of financial state until billions of Indonesian Rupiah (IDR). Almost 21,63 billion IDR of financial state was stolen by the corruptors (https://antikorupsijateng. wordpress.com). As many cases found and revealed in Central Java, it can be seen that inspectorates in Central Java reveal the cases in the field, compared with ever before in which the cases were stopped due to gratification. Therefore, this supports the writer to study on government internal auditors (inspectorate) of Central Java Province whether they have bravery to reveal the findings in field as whistleblower so that it can support good governance and clean government.

\section{LITERATURE REVIEW AND HYPOTHESES DEVELOPMENT}

\section{Literature Review}

Proportional behaviour theory can explain whistleblower behaviour in urgent situation, but it is constantly depended on the nature of cases and actor involved in the situation. Brief and Motowidlo (1986) stated that whistleblowing is one of 13 forms of the prosocial organizational behavior. One of the behaviours is objection of the organization members to directions, procedures or policies which are probably considered unethical, illegal or bringing to a organizational disaster in long term, but they cannot show or change it directly. Therefore, they probably can do whistleblowing and report it to the other individual or agencies having position to correct it. This is in line with Miceli (1985) who stated that whistleblowing behaviour is considered as a proportional behaviour because the behaviour will generally have benefit either for the others (organizations) or for whistleblower himself.

Government Intern Supervision Apparatus (APIP) is an organization unit of Central Government, Local Government, State Ministry, State Institution, and Non Department of State Institution having tasks and functions in monitoring their authorities environment. As the Government Intern Supervision Apparatus (APIP), province inspectorate has duties to determine whether the policies and procedures signed by governor are obeyed and run as the plan, to decide either good or bad of local assets maintains, and to determine the reliability information resulted from the unit and Regional Work Unit (SKPD). Audit is one of supervision parts which consist of looking for information about what has been done by an institution inspected, comparing the result with criteria determined, and agreeing or rejecting the result by giving recommendation to correct.

Whistleblowing system is expected to be an effective tool to minimize fraud in a company or government. Sonny Keraf (2008:172) argued that Whistleblowing is an action done by a person or several employees to leak the fraud carried out by a firm or his boss to another party. According to Lubis (2009), auditor must obey Ethical Code assigned. Standard of Audit and Ethical Code as an integral part of standard of audit must be referred in carrying out the audit.

Kreitner and Kinicki (2005) explained that locus of control is an individual belief which influences events regarding to life. The more belief of the individual in reaching a goal, the possibility to realize it is greater. A person with high internal locus of control has stronger level of belief. He is able to overcome various problems of life and to make important decision in life. The result of internal locus of control is derived from his own activities, (Kreitner \& Kinichi 2005). Besides, organizational commitments influence the intention to do whistleblowing. This implies the relation between employees and company or organization actively, because employees performing high commitment to the organization have greater desires in giving power and responsibility to support the welfare and successfulness of the organization where they work. They will show positive attitude and behaviour, have spirit to defend their organization, try to increase achievements, and possess a definite belief to achieve the goal of the organization, (Kuryanto, 2011). 


\section{Hypotheses Development}

The Influence of Ethical Judgment to Auditor Intention to Whistleblowing.

The attitude of ethical judgment of auditor is an auditor who stands on the existence of moral values and do not break it. Falah (2006) explained that a person's ability to act ethically is very influenced by individual sensitivity. An important factor in assessing ethical behaviour is individual awareness as agent of morality. This can be judged through the ability to realize ethical values in a decision which is called as ethical sensitivity. Prosocial behaviour theory explained that ethical judgment is contextual aspect of prosocial behaviour characteristics antecedent in which it influences mood affecting on the intensity in doing whistleblowing. Chiu (2002, 2003) investigated the influence of individual ethical judgement of Chinese managers and professionals to whistleblowing intention. The study showed that there was a strong positive relation between ethical judgement and whistleblowwing intention. Therefore, the study proposes a hypothesis:

H1: The higher ethical owned by internal auditors, the more possible to do whistleblowing.

\section{The influence of Locus of Control to Auditor intention to Whistleblowing}

A person having internal locus of control tends to rely on himself to right or wrong and tends to accept the consequences of his behaviour. Whistleblowing is considered as an ethical action, so that whistleblower candidate is expected to have the nature of internal locus of control. This belongs to antecedents contextual of prosocial behavior theory, in which when a person encounters a problem, he will be influenced by the way of the individual stabilizes the situation. Furthermore, if he has a good self control, there is possibility that he will report the fraud found to the authorities, to the leader or publish in media. Individual having internal locus of control is potentially to be whistleblower, as he is responsible and strive to control to what happens surround him. Besides, he believes that everything obtained is the result of his works and efforts. Chiu (2003) explained that Chinese manager tended to do whistleblowing in his workroom. Other researchers, Chiu (2003); Curtis and Taylor (2009) found that locus of control was significant to reveal secret of USA public accountants. Based on the explanation, the hypothesis proposed is :

H2: Auditor having internal locus of control will be braver to whistleblowing.

\section{The influence of Organizational commitments to Auditor intention to Whistleblowing}

Organizational commitments imply the relation between employees and company or organization actively for employees showing high commitment to the organization have desire to give power and deeper responsibility to support welfare and successfulness in their workplace. They will show positive attitude and behaviour, have spirit to defend his organization, attempt to increase the achievement, and have a strong belief to manifest the goal of organization (Kuryanto, 2011). Referring to prosocial organizational behaviour theory, it can be concluded that whistleblowing action is an employee showing a form of organizational commitment to keep the organization from unethical or illegal threats. Employees with high affective commitments tend to do internal whistleblowing (reporting fraud to the authorities) in organization compared with external whistleblowing, when it is related to whistleblowing. Mesmer-Magnus and Viswesvaran (2005) proposed that organizational commitments positively correlated with reporting intention and real reporting. Therefore, the hypothesis proposed is as follows

H3: the higher organizational commitments, the more possible to do Whistleblowing.

\section{RESEARCH METHOD}

\section{Population, Sampling, and Technique of Collecting Data}

Population used in this research was all auditors working in Inspectorate of Central Java Province, Semarang Regency and Semarang City. Sampling technique used was coviniece sampling. This means that sampling technique is conducted with spreading a number of questionnaire and analyzing it based on the questionnaires. 


\section{Dependent Variable}

Variable in this research is Policy National Committee. Governance (2008:3) defined that whistleblowing is revealing of violation action or breaking the law, unethical or immoral action or other actions disrupting organizations or stake holders done by employees or organizational leaders to the organization or other institutions in which they can take action of the violation. This revealing is conducted confidentially. Sony Keraf (2008:172) stated that whistleblowing is actions of an employee or several employees to inform the fraud done by either the organization or the leader to other parties. The expected Whistleblowing system can be an effective tool to minimize fraud in company or government.

\section{Independent variable}

Ethical Judgment

According to Maryani and Ludigdo (2001) ethics is a set of rules or guidance governing human behaviour for either the obligation or the prohibition of a group of human or society or a profession. Respondents were asked to show their perception on ethical level in each four sketches.

\section{Locus of Control}

Locus of control is as an individual belief in which he can influence the events regarding to his life, (Kreitner and Kinicki, 2003). A person with high internal locus of control has stronger belief level.

\section{Organizational Commitment}

Organizational commitment implies the relation between employees and company or organization actively, because employees showing high commitment to the organization have desire to give power and deeper responsibility to sustain welfare and successfulness in their workplace. They will show positive attitude and behaviour, have spirit to defend his organization, attempt to increase the achievement, and have a strong belief to manifest the goal of organization (Kuryanto, 2011). Organizational commitment is measured with an instrument which consists of affection organizational commitment and continuance organizational commitment.

\section{Method of Data Analysis}

To examine the hypothesis in this research, multiple linear regression analysis were used. Examination of hypothesis was conducted through stages test of data quality, test of classical assumption, test of determination coefficient, and test of hypothesis.

\section{FINDINGS AND DISCUSSIONS}

\section{General Description of Respondents}

The number of questionnaires spread in this research was 53 questionnaires and distributed in the office of Inspectorate of Central Java Province, Inspectorate of Semarang city, inspectorate Semarang Regency. The summary of the number questionnaires can be seen in the following table 1:

Table 1. Summary of Questionnaires

\begin{tabular}{lc}
\hline \multicolumn{1}{c}{ Description } & Number \\
\hline Total of spread questionnaires & 53 \\
Total of missing questionnaires & $(2)$ \\
Questionnaires with incomplete answer & $(0)$ \\
Questionnaires analyzed & 51 \\
\hline
\end{tabular}

\section{Descriptive Statistics}

In this research, data used was made with likert scale 1-5. It means that measurement of quantified scale is scored or numbered in which the number shows a 
position, on condition the smallest number indicates the lowest values. The result of descriptive statistics will be presented in the following table:

Table 2. Table 2. Result of Descriptive Statistic

\begin{tabular}{lcccccc}
\hline \multirow{2}{*}{ Variable } & \multicolumn{2}{c}{ Theoretical } & \multicolumn{2}{c}{ Empirical } & Theoretical & Empirical \\
\cline { 2 - 5 } & Min & Max & Min & Max & Median & average \\
\hline Ethical Judgement & 4 & 20 & 11 & 19 & 12 & 16,66 \\
Locus of Control & 8 & 40 & 20 & 40 & 24 & 29,10 \\
Organizational Commitments & 7 & 35 & 20 & 33 & 21 & 26,10 \\
Whisleblowing intensity & 6 & 30 & 14 & 40 & 18 & 23,36 \\
\hline
\end{tabular}

\section{Test of Data Quality}

Test of Validation

Test of validation is used to measure validation of the questionnaires. It is considered valid when the question in the questionnaire can express entity measured by the questionnaire, (Ghozali, 2011). The validation test is conducted by comparing corrected item total correlation with $\mathrm{r}$ table. An indicator is valid when it has correlation value above $r$ table by test two side. In this research the number of sample is $(n)=51$ and the amount of $\mathrm{df}$ is counted $51-2=49$ with $\mathrm{df}=49$ and alpha $=0,05$ in which $\mathrm{r}$ table $=0,0276$ (see $r$ table in $\mathrm{df}=49$ with test two side). Based on the pattern, it is recognized that all questions are valid.

\section{Reliability Test}

Reliability test is conducted to measure a questionnaire as the variable indicator or construct. A questionnaire is recognized reliable when the answer to the questions are consistent or stable from time to time. (Ghozali, 2011). Reliability test will be conducted with Cronbach Alpha. The summary of reliability test can be seen in the following table

Table 3. Result of Reliability Test

\begin{tabular}{lcc}
\hline \multicolumn{1}{c}{ Variable } & Cronbach Alpha & Description \\
\hline Ethical Judgement & 0,620 & Reliable \\
Locus of Control & 0,937 & Reliable \\
Organizational Commitment & 0,754 & Reliable \\
Intensity to do Whistleblowing & 0,765 & Reliable \\
\hline
\end{tabular}

\section{Multiple Regression Analysis}

Analysis of multiple linear regression is a statistical method to examine the influences between bound variable (metric) and free variable (metric). This research used statistical method of multiple regression analysis. Bound variable (whislteblowing intention) in this research used metric while free variable (ethical judgment, locus of control, organizational commitment) used metric, and free variable (gender) used non metric variable. The result of hypothesis test using SPSS program will be presented in table 4 as follows:

Table 3. Result of Multiple Regression Analysis

\begin{tabular}{lrrrrrrr}
\hline & \multicolumn{2}{c}{$\begin{array}{c}\text { Unstandardized } \\
\text { Coefficients }\end{array}$} & $\begin{array}{c}\text { Standardized } \\
\text { Coefficients }\end{array}$ & \multicolumn{3}{c}{$\begin{array}{c}\text { Collinearity } \\
\text { Statistics }\end{array}$} \\
\cline { 2 - 8 } Model & \multicolumn{1}{c}{ B } & Std.Error & Beta & \multicolumn{1}{c}{ T } & Sig. & Tolerance & VIF \\
\hline (Constant) & -.048 & 4.942 & & -.010 & .992 & & \\
Ethical & .932 & .213 & .428 & 4.382 & .000 & .907 & 1.103 \\
Loc & .164 & .080 & .247 & 2.049 & .046 & .596 & 1.677 \\
Commitment & .338 & .132 & .288 & 2.560 & .040 & .684 & 1.462 \\
\hline
\end{tabular}

The Influence of Ethical Judgment to Auditor Intention in doing Whistleblowing

Based on table 4, it can be seen that the test result of the influence ethical judgment to auditor intention to whistleblowing showed statistical value for 4.382 with significance $0 \% ; 5 \%$. The smaller of significance value of $5 \%$ showed that ethical judgement has significant effect to the intensity to do_whistleblowing toward positive. In 
addition, coefficients toward positive showed that auditor having high professional of ethical judgement will also have high intensity to whistleblowing. This research shows that there is an influence of ethical judgement to the intensity to whistleblowing so that this is in line with prosocial behavior theory. This theory mentioned that ethical judgement is an aspect of characteristics antecedent contextual of proportional behaviour in which it influences mood effecting the intensity in doing whistleblowing.

\section{The Influence of Locus of Control to Auditor Intention in doing Whistleblowing.}

Based on table 4, it can be seen that test result of the influence locus of control to the intensity in doing whistleblowing demonstrated statistical value $\mathrm{t}$ for 2.049 with significancy $4,6 \% ; 5 \%$. The smaller significance value of $5 \%$ showed that locus of control has influence positive significantly to the whistleblowing intensity. As the positive coefisients, it means that auditors having high internal locus of control will be braver in doing whistleblowing. This research shows that there is an influence of internal locus of control to the intensity in doing whistleblowing so that this is in line with prosocial behavior theory. Locus of control includes antecedents contextual of prosocial behavior theory, in which a person having a problems will be influenced by the way of every individual in controlling the situation.

If a person has good self control, there is possibility to report a fraud found to the authorities, to the leader, or to publish in media. Individual having internal locus of control is potentially to be a whistleblower, because he is responsible and strive to control to what happen surround him. Besides, he believes that everything obtained is the result of his works_and efforts.

\section{The Influence of Organizational Commitment to Auditor Intention in doing Whistleblowing.}

Based on table 4, it can be seen that the test result of the influence of organizational commitment to auditor intention in doing whistleblowing showed statistical value $t$ for 2.560 with significance $1,4 \% ; 5 \%$. The smaller significant value of $5 \%$ showed that organizational commitment effect significantly to the intensity in doing whistleblowing. This is in line with prosocial organizational behaviour theory in which whistleblowing action of an employee shows a form of organizational commitment to protect the organization from unethical or illegal threats. Organizational commitment of an employees is loyalty of employee to the organization reflected with their high involvement to protect the organization from unethical or illegal threats to achieve organizational goals.

\section{CONCLUSIONSAND LIMITATIONS RESEARCH}

\section{Conclusions}

1. Ethical judgement influences positively and significantly to the whistleblowing intensity. Auditor with high ethical judgement tends to have high intensity to whistleblowing

2. Locus of control impacts positively and significantly to the whistleblowing intensity. Auditor with internal locus of control tends to have high intensity to whistleblowing

3. Organizational commitment impacts significantly and positively to whistleblowing intensity. Auditor with organizational commitment tends to have high intensity to whistleblowing

\section{Limitation and Sugesstion}

The limitation of this study is research scope limited for internal auditors of inspectorates in Central Java Province, Semarang Regency, and Semarang City, so that sample is relatively a little as the number of auditors working there. This leads to low of statistical power as a result of experiment research. The next research is hoped to expand the samples and to do research on how far the causes of the difference between the level anticipative socialization and professional commitment to whistleblowing. 
This can be conducted by researching on the influence of culture and idealism to the differences.

\section{REFERENCES}

Ahmad, Syahrul. A., M. Smith, dan Z. Ismail, dan R. M. Yunos: 2012, 'Internal Whistleblowing Intentions: A Study Demographic and Individual Factors', Journal of Modern Accounting and Auditing, ISSN 1548-6583 Vol. 8, No. 11, 1632-1645.

Arnold, D. dan Ponemon, L. 1991. "Internal Auditors' Perception of Whistleblowing and the Influence of Moral Reasoning; An Experiment". Auditing: A Journal of Theory and Practice, 1-15.

Brief, A. P., \& Motowidlo, S. J. (1986). Prosocial organizational behaviors. The Academy of Management Review, 11(4), 710-725.

Chiu, R. K. (2002). Ethical judgement, locus of control, and whistleblowing intention: A case study of mainland Chinese MBA students. Managerial Auditing Journal, 17(9), 581-587.

Chiu, R. K. (2003). Ethical judgment and whistleblowing intention: Examining the moderating role of locus of control. Journal of Business Ethics, 43(1/2), 65-74.

Duska, R., B. R. Duska, dan Julie Ragatz: 2011, Accounting Ethics, Second Edition (John Wiley \& Sons: Amerika Serikat).

Donnelly, D. P., Quirin, J. J., \& O'Bryan, D. (2003). Auditor acceptance of dysfunctional audit behavior: An explanatory model using auditors' personal characteristics. Behavioral Research in Accounting, 15, 87-110.

Dozier, J. B., \& Miceli, M. P. (1985). Potential predictors of whistle-blowing: A prosocial behavior perspective. Academy of Management Review, 10(4), 823836.

Falah, Syaikhul. 2006. Pengaruh Budaya Etis Organisasi dan Orientasi Etika Terhadap Sensitivitas Etika (Studi Empiris Tentang Pemeriksaan Internal di Bawasda Pemda Papua). Tesis. Program Pascasarjana. Universitas Diponegoro. Semarang.

Ghozali, I. 2011. Aplikasi Analisis Multivariate dengan Program IBM SPSS 19. 5 ed. Semarang: Badan Penerbitan Universitas Diponegoro.

Kell, W.G., R.N. Johnson dan W.C. Boynton. 2002. Modern Auditing. Edisi Ketujuh. Jilid I. Jakarta: Penerbit Erlangga.

Keraf, Sonny. 2008. Etika Bisnis, Penerbit Kanisius, Yogyakarta.

Komite Nasional Kebijakan Governance (KNKG). (2008). Pedoman Umum GCG Indonesia, Jakarta.

Kreitner, Robert and Angelo Kinicki. 2005. PerilakuOrganisasi (Orgaizational Behavior). Jakarta: Salemba Empat.

Kuryanto, Benny \& Muchamad Syafrudin. 2011. Pengaruh Modal Intelektual Terhadap Kinerja Perusahaan. Makalah Disampaikan dalam Simposium Nasional Akuntansi XI. Pontianak: 23-24 Juli.

Lubis, Haslinda. 2009. Pengaruh Keahlian, Independensi, Kecakapan Profesional, dan Kepatuhan pada Kode Etik terhadap Kualitas Auditor pada Inspektorat Provinsi Sumatera Utara, (Tesis tidak dipublikasikan, Universitas Sumatera Utara).

Maryani, T. \& U. Ludigdo. (2001).Survei Atas Faktor-Faktor yang Mempengaruhi Sikap dan Perilaku Etis Akuntan. Jurnal TEMA 2 (1): 49-62.

Mesmer-Magnus, J. R., \& Viswesvaran, C. (2005). Whistleblowing in organizations: An examination of correlates of whistleblowing intentions, actions, and retaliation. Journal of Business Ethics, 62(3), 277-297.

Sulistomo, A., and Prastiwi, A. (2011). Persepsi Mahasiswa Akuntansi Terhadap Pengungkapan Kecurangan. Skripsi, Universitas Diponegoro, Semarang.

Taylor, E. Z., \& Curtis, M. B. (2009). An examination of the layers of workplace influences in ethical judgments: Whistleblowing likelihood and perseverance in public accounting. Journal of Business Ethics, 93(1), 21-37. 